\title{
Calcium dysregulation in Alzheimer's disease: Recent advances gained from genetically modified animals
}

\author{
Ian F. Smith, Kim N. Green, Frank M. LaFerla* \\ Department of Neurobiology and Behavior, University of California, 1109 Gillespie Neuroscience Building, \\ Irvine CA 92697-4545, USA
}

Received 20 June 2005; accepted 28 June 2005

\begin{abstract}
Alzheimer's disease is a progressive and irreversible neurodegenerative disorder that leads to cognitive, memory and behavioural impairments. Two decades of research have implicated disturbances of intracellular calcium homeostasis as playing a proximal pathological role in the neurodegeneration associated with Alzheimer's disease. A large preponderance of evidence has been gained from the use of a diverse range of cell lines. Whilst useful in understanding the principal mechanism of neurotoxicity associated with Alzheimer's disease, technical differences, such as cell type or even the form of amyloid-beta used often underlie conflicting results. In this review, we discuss recent contributions that transgenic technology has brought to this field. For example, the triple transgenic mouse model of Alzheimer's disease has implicated intraneuronal accumulation of the amyloid-beta peptide as an initiating factor in synaptic dysfunction and behavioural deficits. Importantly, this synaptic dysfunction occurs prior to cell loss or extracellular amyloid plaque accumulation. The cause of synaptic dysfunction is unknown but it is likely that amyloid-beta and its ability to disrupt intracellular calcium homeostasis plays a key role in this process.
\end{abstract}

(C) 2005 Elsevier Ltd. All rights reserved.

Keywords: Alzheimer's disease; Calcium dysregulation; Presenilin; Amyloid; Alzheimer's; Transgenic

\section{Introduction}

Alzheimer's disease (AD) is the most common form of age-related dementia in the elderly. Unfortunately, as the average age of our population continues to increase, there is also a concomitant rise in the number of people afflicted with this debilitating disorder. Currently, it is estimated that one in 10 persons over 65 , and more than a third of all people over 80 have AD. According to United Nations population projections, it is estimated that 370 million people will be older than 80 years by 2050 [1]. The aging of the world's population, therefore, will potentially pose an immense social and economic burden on future societies as this susceptible cohort continues to rapidly expand. Thus, a better understanding

\footnotetext{
* Corresponding author. Tel.: +1 949824 1232; fax: +1 9498247356

E-mail address: laferla@uci.edu (F.M. LaFerla).
}

of the molecular events underlying $\mathrm{AD}$ will no doubt prove invaluable for combating this affliction.

Alois Alzheimer first described the pathological hallmarks of this disorder in 1906, observing strange alterations of the neurofibrils and foci, which were built up by a "peculiar substance" [2]. Our understanding of the molecular signatures of these hallmark lesions have been refined since his initial description. We now appreciate that neuritic and diffuse senile plaques are composed primarily of a small peptide called $\beta$-amyloid $(\mathrm{A} \beta)$, whereas the intracellular neurofibrillary tangles are composed of aggregates of hyperphosphorylated tau protein. The neuritic (or senile) plaques are dense deposits of $A \beta$ around which dystrophic neuronal cell processes are observed. Plaques are generally noted within various parts of the brain but are especially abundant within the cerebral cortex, hippocampus and amygdala [3]. It is the gradual build-up of $A \beta$ that is generally believed to account for the onset of this form of dementia [4]. Strong support 
for this hypothesis comes from human genetic data although recent advances in transgenic models have also provided critical corroborating evidence [5-7]. The preponderance of evidence supports a role for $A \beta$ as the initial trigger of this disease in a process known as the amyloid cascade hypothesis. However, even though $A \beta$ may trigger all forms of this disease, it should not preclude investigating and understanding other molecular and cellular aspects of AD even if they lie downstream of $A \beta$. In this regard calcium dysregulation, for example, represents a critical molecular defect that potentially can be attenuated with appropriate therapies. Moreover, it is interesting to note that $A \beta$ and tau can both be influenced by calcium dysregulation, and alternatively the accumulation of these lesions can perturb calcium regulation. The point of this article is not to exhaustively review the entire body of literature concerned with calcium and $\mathrm{AD}$ but to focus on recent data generated using in vivo models. Here, we discuss advances in understanding the role of calcium dysregulation in $\mathrm{AD}$ with particular emphasis on the contribution of genetically modified animals. For a more comprehensive review we refer the reader to a recent review [8].

\section{APP processing}

Before we describe the evidence for calcium dysregulation in $A D$, it is critical to understand the process by which $A \beta$ is generated and the influence that mutations have on the processing of amyloid precursor protein (APP). A $\beta$ is generated by the sequential cleavage of APP, a type I integral membrane protein anchored to the plasma membrane and internal membranes of the ER, Golgi and trans-Golgi apparatus. A $\beta$ is generated in very small quantities in normal healthy individuals and does not typically build up to very high levels [9]. However, in individuals afflicted with $A D$, differential processing of APP or the failure to degrade $A \beta$ leads to its excessive accumulation.

Endoproteolysis of APP is achieved by the sequential cleavage by groups of enzymes or enzyme complexes termed $\alpha-, \beta-$, and $\gamma$-secretases. For $\alpha$-secretase there are currently two members of the ADAM family (a disintegrin and metalloproteinase-family) of proteases, ADAM-10, and ADAM-17, the latter of which is also referred to as tumour necrosis factor $\alpha$ converting enzyme (or TACE), that have been suggested as likely candidiates $[10,11]$. Several groups

(A)

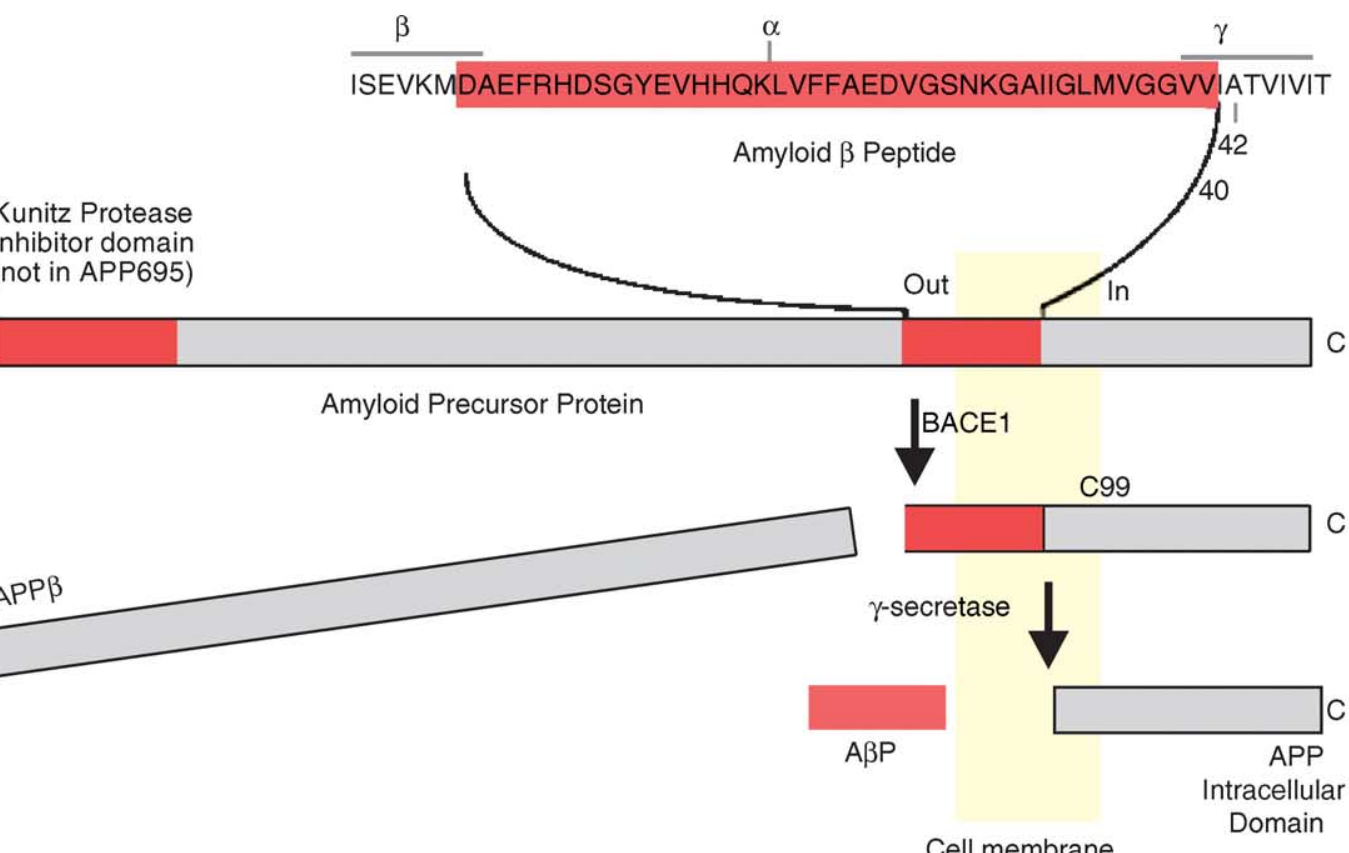

(B)

$\mathrm{N}$ (not in

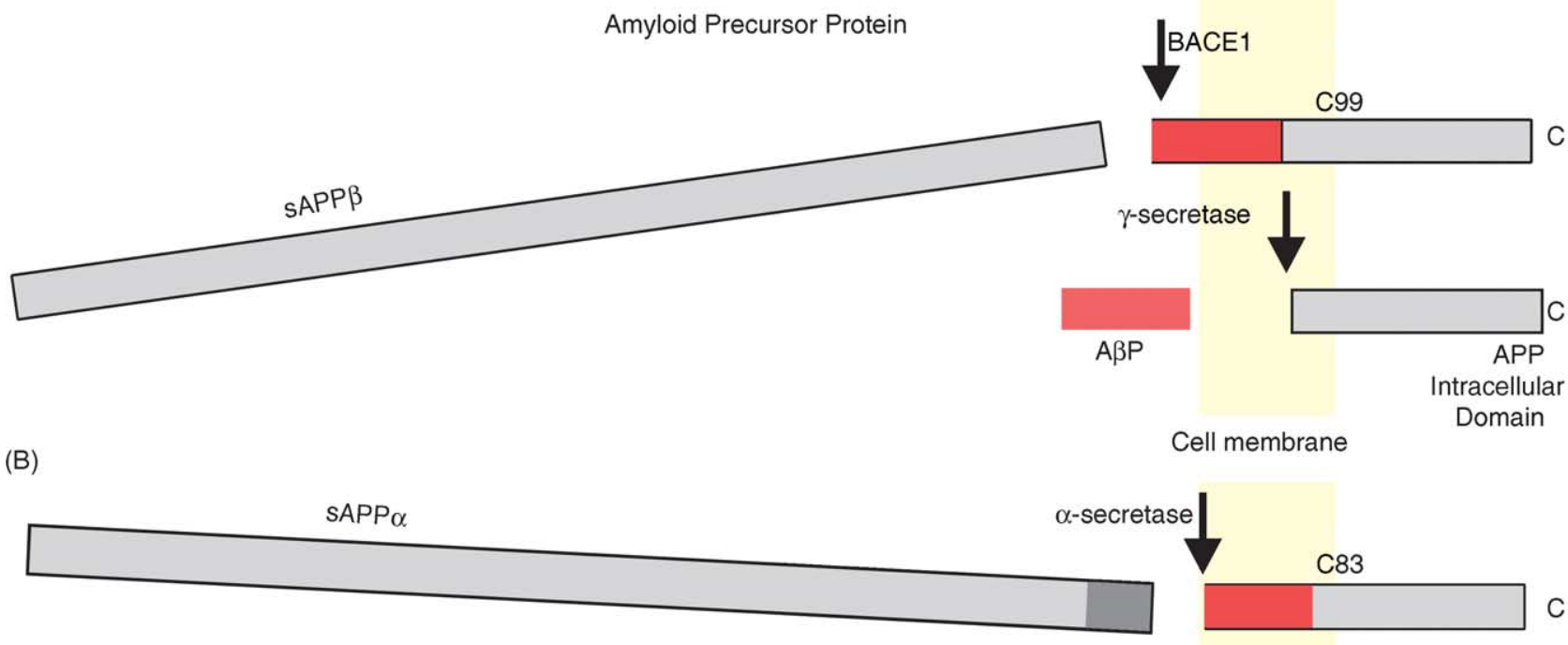

Fig. 1. Proteolytic processing of the amyloid precursor protein (APP). (A) Amyloidogenic processing of APP leads to the liberation of the $4 \mathrm{kDa} A \beta$ peptide. For this to occur, APP must first be cleaved by BACE which releases a large ectodomain called sAPP $\beta$ whereas the remaining 99 amino acid carboxy terminal (C99) is retained within the membrane. Subsequent cleavage of C99 by the $\gamma$-secretase complex leads to the liberation of the A $\beta$ peptide. (B) Non-amyloidogenic processing of APP precludes A $\beta$ formation. Enzymatic cleavage of APP by $\alpha$-secretase cleaves APP within the A $\beta$ region of APP and thus precludes its formation. $\alpha$-secretase cleavage liberates a large ectodomain called sAPP $\alpha$, which is released into the extracellular space, whereas an 83 amino acid stub, C83, is retained within the membrane and can be further processed by $\gamma$-secretase (not shown). The vast majority of APP is processed in the non-amyloidogenic pathway. 
have identified the $\beta$-secretase ( $\beta$-site APP cleaving enzyme or BACE) as a type I integral membrane protein belonging to the pepsin family of aspartyl proteases [12-14]. The identity of the $\gamma$-secretase has been proposed to be a complex of enzymes composed of presenilin-1 or -2, (PS1 and PS2), nicastrin, aph-1 and pen-2 [15-18].

The cleavage and processing of APP can be divided into two classes: a non-amyloidogenic pathway and an amyloidogenic pathway (Fig. 1). In the non-amyloidogenic pathway, a large proportion of APP is cleaved by $\alpha$-secretase producing an N-terminal fragment ( $\mathrm{SAPP} \alpha)$ that is secreted into the extracellular medium [1]. The resulting C-terminal fragment $(\mathrm{C} 83)$ in the membrane is retained within cells and subsequently cleaved by the $\gamma$-secretase producing a short fragment termed p3 [19]. Importantly, cleavage by the $\alpha$ secretase occurs within the $A \beta$ region, thereby precluding its formation.

Alternative cleavage of APP can also occur under physiological conditions via the amyloidogenic pathway, with cleavage by the $\beta$-secretase resulting in the production of a slightly smaller form of APP (sAPP $\beta$ ) and a slightly larger C-terminal fragment (C99), retained within the membrane [1]. Subsequent cleavage of this fragment (between residues 39-43) by $\gamma$-secretase liberates an intact $A \beta$ species. Most of the full length $A \beta$ species terminates at residue $40\left(A \beta_{1-40}\right)$, whereas a small proportion (approximately 10\%) are the 42 residue variant $\left(A \beta_{1-42}\right)$. The $A \beta_{1-42}$ variant is more hydrophobic and is thus much more prone to fibril formation than $A \beta_{1-40}$; it is also the predominant species found in cerebral plaques [20]. A $\beta$ can exist in a variety of forms, including monomers, oligomers, and fibrils [21].

\section{Genetics and AD}

Most cases of AD are not caused by a specific genetic defect but are sporadic in nature and are typically characterized by a later age of onset. However, there are a significant number of cases that are inherited in an autosomal dominant manner, and generally these forms manifest at an earlier age of onset. Several such mutations occur within the APP gene and cluster around the various secretase sites [1] Surprisingly, APP mutations account for a small percentage of FAD cases. Mutations in the genes encoding PS1 and PS2, found on chromosomes 14 and 1, respectively, serve as the major loci for FAD [22,23]. Whilst over 135 individual mutations have been linked with PS1, only 10 have thus far been linked with PS2 [24]. PS1 mutations cause an aggressive form of FAD with a particularly early age of onset, whilst PS2 mutations result in a form of FAD that is more akin to sporadic AD, bearing a later age of onset [24]. A key feature of the identified clinical mutations is that they all cause elevated production of $A \beta_{1-42}$. Indeed biochemical assays in plasma and cultured human skin fibroblasts revealed a selective elevation of $A \beta_{1-42}$ in these patients [25].

\section{Calcium homeostasis and knowledge gained from in vivo studies}

In addition to direct effects on $A \beta$ formation, presenilin mutations have profound effects on cellular calcium homeostasis [26]. This feature of presenilins has received a great deal of attention over the past 10 years because of its potential role in contributing to the neurodegenerative phenotype. Along these lines, it is notable that every clinical mutation investigated appears to disrupt calcium signalling (Table 1).

Initial observations regarding the role of the presenilins in calcium signalling were identified using in vitro expression studies, with a consistent finding being an upregulation of calcium release resulting from overexpression of mutant PS1 [26-29]. Soon thereafter it was realized that PS2 mutations also resulted in a similar enhanced release of calcium from intracellular stores [30]. Likewise, knocking out PS1 also disrupts calcium signalling [31]. This molecular defect that is exerted by both PS1 and PS2 mutations is unlikely to be an epiphenomenon but rather likely highlights a shared pathway that can cause neurodegeneration. Thus, caution needs to be exercised when considering the therapeutic efficacy of $\gamma$-secretase inhibitors, not only because of the potential for adverse side-effects due to the large number of substrates that undergo presenilin-mediated proteolysis, but also because of their potential for untoward effects on calcium signalling.

The overwhelming majority of these initial studies examining the effects of PS1 and PS2 mutations were performed using overexpression systems in diverse cell lines such as Xenopus oocytes or PC12 cells. These studies have helped to elucidate the principal pathophysiological roles for presenilins in modulating the intracellular calcium environment. A

Table 1

Different presenilin mutations affecting calcium homeostasis

\begin{tabular}{llll}
\hline Gene & Mutation & Experimental system & Selected References \\
\hline PS1 & M146V & Xenopus oocytes & {$[29]$} \\
& & PC12 cells & {$[26,27]$} \\
& & Transgenic mice & {$[39,87]$} \\
& "Knock-in" mice & {$[28,32,88]$} \\
& M146L & Transgenic mice & {$[36,87]$} \\
H163R & Transgenic mice & {$[89]$} \\
A246Q & FAD fibroblasts & {$[40,90-98]$} \\
A246E & Transgenic mice & {$[37]$} \\
L286V & PC12 cells & {$[26,27,99-101]$} \\
& Transgenic mice & {$[89]$} \\
AE9 & SH-SY5Y cells & {$[102-104]$} \\
Null & Knock-out mice & {$[31,105,106]$} \\
& N141I & Xenopus oocytes & {$[30,107]$} \\
& Transgenic mice & {$[108]$} \\
& HEK293 & {$[107]$} \\
& M239V & Xenopus oocytes & {$[30]$} \\
& HEK293 & {$[107]$} \\
M239V & Xenopus oocytes & {$[30]$} \\
M239I & FAD fibroblasts & {$[109]$} \\
& HEK293 & {$[109]$} \\
& & Knockout mice & {$[31]$} \\
& &
\end{tabular}


complication with this approach, however, is that in addition to the difficulties of comparing effects between diverse cell lines, an inherent problem is the inability to accurately control expression of foreign proteins often resulting in the analysis of systems in which there is supraphysiological levels of the protein of interest.

In 1999, George Martin's group generated geneticallymodified mice where the human PS $1 \mathrm{M} 146 \mathrm{~V}$ mutation was 'knocked-in' to the endogenous locus, leading to the exclusive production of the mutant protein in the absence of the endogenous wild-type protein [32]. This knock-in mouse presented researchers with an opportunity to study the in vivo effects of mutant PS1 on calcium homeostasis in diseaserelevant cell types. Notably, the majority of the experiments focused on the role for mutant PS1 altering intracellular calcium homeostasis have proven remarkably consistent with earlier expression studies in a diverse range of cell lines. Again, the recurrent observation supports a role for mutant PS1 causing exaggerated intracellular calcium signalling. The treatment of PS1 mutant cells with ER calcium channel inhibitors such as dantrolene or xestospongin, which inhibits the $\mathrm{IP}_{3}$ or the ryanodine receptor respectively, protects cells from toxic insults, including $A \beta[26,33]$.

Our research team here at UCI was among the first groups to investigate calcium signalling in brain slices. Using flash photolysis and two-photon imaging of brain slices from 4-5 week old mice, we found that $\mathrm{IP}_{3}$-mediated calcium release was more than threefold greater in the PS1 mutant mice relative to age matched NonTg controls [34]. Not only was the overall amplitude different, but the breakdown of group responses was also altered. Whereas the NonTg samples broke down into $20 \%$ non-responders, $33 \%$ weak responders and $47 \%$ strong responders, the corresponding mutant PS1 group consisted predominantly (93\%) of strong responders. Therefore, the clinical mutation in PS1 served not only to exaggerate $\mathrm{IP}_{3}$-mediated calcium responses but also to increase the relative number of neurons that produce a strong calcium elevation rather than a weaker one. It was concluded that the enhanced response observed in mutant PS1 mice was attributable to an increase in the size of intracellular calcium stores. This overload of calcium stores has implications for the pathogenesis of $\mathrm{AD}$ as destabilization of intracellular calcium signalling could cause neurodegeneration and memory impairments by affecting synaptic plasticity. For a more comprehensive discussion of the role for intracellular calcium stores modulating synaptic plasticity we refer the reader to a recent review [35].

Changes in internal calcium stores might have potent consequences for both short and long-term plasticity, such as the induction of long-term potentiation (LTP). Indeed we and others have shown enhanced LTP and increased medium and late afterhyperpolarizations (which are mediated by calcium sensitive potassium channels) in mutant PS1 mice [34,36-38]. The underlying molecular mechanisms accounting for these findings are still not fully understood and may be due to an enhancement of the total amount of stored calcium within the
ER or it may also be due to alterations in the release kinetics of stored calcium.

To investigate the relationship between the pathogenesis of $\mathrm{AD}$ plaque and tangle pathology, we developed a triple-transgenic mouse model ( $3 \times \mathrm{Tg}-\mathrm{AD})$ by introducing two transgenes $\left(\mathrm{APP}_{\mathrm{swe}}\right.$ and taup301L) into the germline of the PS1 mutant knock-in mouse [38]. These transgenes are expressed under the transcriptional control of the Thy 1.2 cassette and develop an age-related neuropathological phenotype that includes both plaque and tangle pathology. Animal models have proven useful in studying the impact of mutant AD-related genes on cellular signaling pathways such as calcium signaling. Along these lines, microfluorimetric measurements were used to investigate disturbances in calcium homeostasis in Fura-2AM-loaded primary cortical neurons from NonTg, PS1 $1_{\mathrm{KI}}$ and 3xTg-AD embryonic mice [39]. Voltage-gated calcium entry was not significantly altered by the expression of any of the transgenes (Fig. 2E). Application of caffeine to $\mathrm{PS} 1_{\mathrm{KI}}$ neurons and $3 \mathrm{xTg}-\mathrm{AD}$ neurons evoked a peak rise of $\left[\mathrm{Ca}^{2+}\right]_{i}$ that was significantly greater than those observed in NonTg neurons (Fig. 2G), although all groups had similar decay rates of their $\mathrm{Ca}^{2+}$ transient (Fig. 2E). This finding suggests that $\mathrm{Ca}^{2+}$ stores are greater in both PS1 $1_{\mathrm{KI}}$ and $3 \times \mathrm{Tg}$-AD neurons as calculated by the integral of the caffeine-induced $\mathrm{Ca}^{2+}$ transient signal (Fig. $2 \mathrm{H}$ ). Western blot analysis indicated that the levels of several $\mathrm{Ca}^{2+}$ binding proteins (SERCA-2B, calbindin, calsenilin and calreticulin) that regulate intracellular calcium storage and cytosolic calcium elevations were unaltered among the various groups. However, steady state levels of the RyR were significantly increased in the cortex of both PS1 $1_{\mathrm{KI}}$ and $3 \times \mathrm{Tg}$ $\mathrm{AD}$ cortex. Based on these findings, we suggest that the enhanced response to caffeine observed in both the PS1 $1_{\mathrm{KI}}$ and $3 \times T g-A D$ neurons may be attributable to increased levels of the RyR facilitating the release of stored $\mathrm{Ca}^{2+}$, although we cannot exclude the possibility that the store size is also enhanced.

How does the expression of mutant PS1 result in these exaggerated responses to $\mathrm{IP}_{3}$ ? The endoplasmic reticulum (ER) contains two main type of calcium release channels, the inositol 1,4,5-trisphosphate receptor $\left(\mathrm{IP}_{3} \mathrm{R}\right)$ and the RyR. Whereas $\mathrm{IP}_{3}$ stimulates calcium release from the $\mathrm{IP}_{3} \mathrm{R}$, calcium ions stimulate the release of calcium through the RyR. One molecular consequence of PS1 mutations is an upregulation in the levels of the RyR [33,39]. Calcium liberated from $\mathrm{IP}_{3}$ sensitive calcium stores can initiate a process known as calcium-induced calcium release (CICR) effectively recruiting RyR-sensitive stores. We and others have shown an increase in calcium liberated from the RyR-senstive pool in cortical neurons islolated from these mice $[33,39]$. Is the enhanced response observed simply due to the recruitment of the RyR-sensitive calcium pool that is releasing its stored calcium at a faster rate? Ongoing experiments in the lab are designed to address this question using RyR antagonists in order to determine if the exaggerated $\mathrm{IP}_{3}$ response can be restored to NonTg levels. 
(A) NonTg

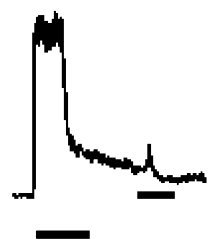

$25 \mathrm{mM}$ caffeine $50 \mathrm{mM} \mathrm{KCl}$

(B) $\mathrm{PSI}_{\mathrm{KI}}$
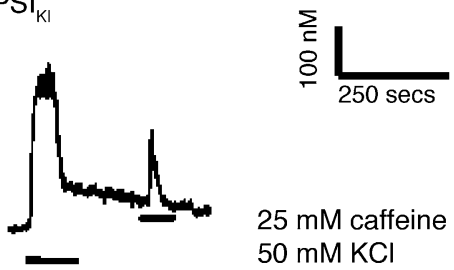

$25 \mathrm{mM}$ caffeine $50 \mathrm{mM} \mathrm{KCl}$

(C) $3 \times \mathrm{Tg}-\mathrm{AD}$

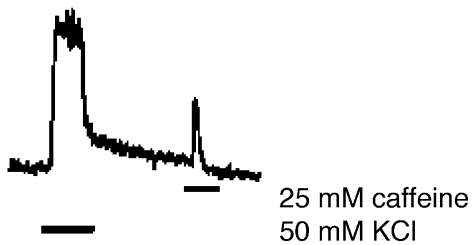

(D)

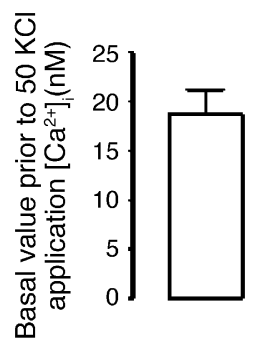

(F)

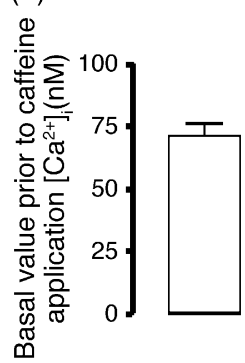

(H)

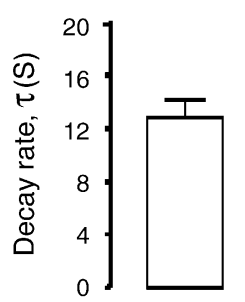

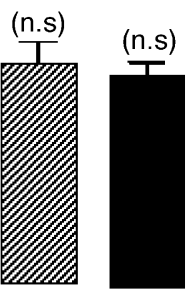

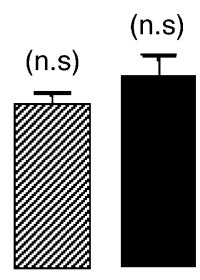

(n.s)

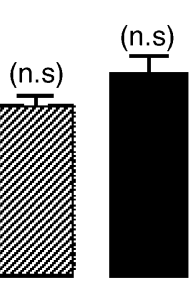

(E)

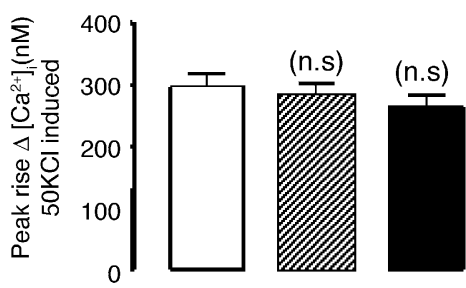

(G)

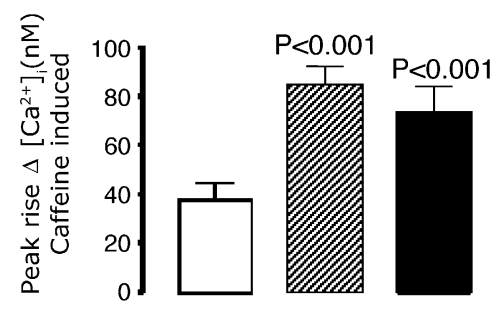

(I)

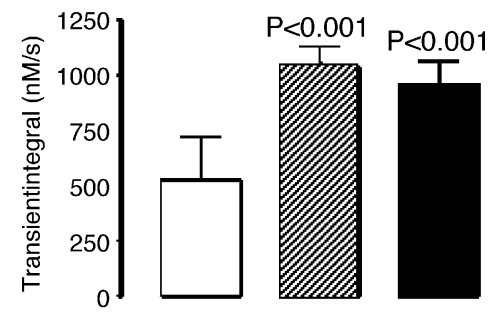

Fig. 2. Caffeine-sensitive calcium signals are enhanced in neurons isolated from $\mathrm{PS} 1_{\mathrm{KI}}$ and $3 \mathrm{xTg}-\mathrm{AD}$ neurons. When depolarized briefly by a $50 \mathrm{mM} \mathrm{KCl}$ pre-pulse in a calcium containing medium, multiple responses to caffeine could be produced. Whilst voltage gated calcium entry was unaltered in $3 \mathrm{xTg}$ - $\mathrm{AD}$ and PS1 $1_{\mathrm{KI}}$ cells with respect to NonTg cells, caffeine-induced rises in intracellular calcium was significantly increased in $3 \times \mathrm{xTg}-\mathrm{AD}$ and PS1 $\mathrm{KI}$ compared to NonTg neurons. Representative rise in intracellular calcium evoked by repetitive stimulation by bath application of $50 \mathrm{mM} \mathrm{KCl}$ followed by $25 \mathrm{mM}$ caffeine in NonTg (A), PS1 $1_{\mathrm{KI}}$ (B) and 3xTg-AD neurons (C). (B) Bar graphs (open bar: NonTG, hatched: PS1 $\mathrm{KI}$, solid bar: 3xTg-AD) indicating mean values from parameters measured from recordings in (A, B and C): basal calcium prior to $50 \mathrm{mM} \mathrm{KCl} \mathrm{(D),} \mathrm{peak} \mathrm{rise} \mathrm{to} 50 \mathrm{mM} \mathrm{KCl} \mathrm{(E),} \mathrm{basal} \mathrm{calcium} \mathrm{prior} \mathrm{to} \mathrm{caffeine}$ application $(\mathrm{F})$, peak rise to $25 \mathrm{mM}$ caffeine $(\mathrm{G})$, decay rate $(\mathrm{H})$ and transient integral of $25 \mathrm{mM}$ caffeine induced rise in calcium (I). $n=21$ non-TG, $n=18$ for PS1 $1_{\mathrm{KI}}$ and $n=25$ for $3 \mathrm{xTg}-\mathrm{AD}$.

The key question that remains to be resolved is the pathophysiological relevance of these findings and how they affect the onset and progression of neurodegeneration in AD. Certainly, dysregulated intracellular calcium stores have been shown to play a role in A $\beta$-induced toxicity in mutant PS1expressing neurons, and disturbances of intracellular calcium homeostasis have been shown to reliably predict the development of $\mathrm{AD}$ years prior to the development of an overt clinical phenotype [40]. However, a role for disturbances of intracellular calcium homeostasis in synaptic dysfunction is still less clear. For example, we have shown that paired pulse facilitation, a measure of short term plasticity was unaltered between NonTg, PS1 $1_{\mathrm{KI}}$ and $3 \mathrm{xTg}-\mathrm{AD}$ mice at 1 month of age. At 6 months of age, there was no difference in facilitation between NonTg and 3xTg-AD mice; however the PS1 $1_{\mathrm{KI}}$ mice exhibited slightly enhanced PPF compared to NonTg [38]. Thus the accumulation of APP proteolytic fragments downregulates the enhanced facilitation imparted by mutant PS1. It is unlikely that tau plays a major role in this process, as transgenic mice containing the same PS1 mutation and that overexpress mutant tau to the same level as the $3 \times \mathrm{Tg}-\mathrm{AD}$ mice continue to show facilitation [38].

The mechanisms underlying PPF are thought to be presynaptic [41] and probably involve residual calcium in the nerve terminal after the first stimulus, leading to increased neurotransmitter release during the second stimulus [42]. The nature of the facilitation of PPF observed in the PS1 $1_{\mathrm{KI}}$ remains to be determined yet may be due to alterations of intracellular calcium handling $[8,28]$ that is negated by the overexpression of APP in the $3 \times \mathrm{Tg}-\mathrm{AD}$ mice.

In addition to the age-related deficits in short term plasticity, the 3xTg-AD mice also show deficits in LTP, a form of plasticity thought to underlie learning and memory [43]. At one month of age, the $3 \times \mathrm{Tg}$-AD showed no impairment, however, at 6 months of age, LTP was severely impaired. There was again a disparity with the PS1 $1_{\mathrm{KI}}$ mice showing significantly higher potentiation during the first $10 \mathrm{~min}$ after HFS compared to the other groups. The LTP response in the dou- 
ble transgenic mice with the mutant PS1 $1_{\mathrm{KI}}$ and the Taup301L transgene was comparable to those observed in NonTg mice; this was an important observation and confirmed that overexpression of mutant tau did not affect the facilitation mediated by the PS1 $1_{\mathrm{KI}}$. This finding suggests further that the pronounced deficits in LTP observed in the 3xTg-AD mice are most likely due to the overexpression of APP, being either as a result of APP expression itself or more likely due to the intraneuronal accumulation of A $\beta$. Notably, these LTP deficits also correspond to the time point when the impairments in learning and memory become evident, a phenomenon that can be reversed by the $A \beta$ immunotherapy [5].

The precise mechanisms and cause of the adverse effects of LTP remain to be determined yet is seems likely that A $\beta$ plays a pivotal role. It has also been demonstrated that neuronal activity modulates the formation and secretion of $A \beta$ peptides in hippocampal slice neurons overexpressing APP, and, likewise that increased production of $A \beta$ leads to synaptic dysfunction in these mice [44]. It is as yet unknown what form of $A \beta$ is responsible for this synaptic dysfunction. There is evidence to suggest that oligomeric forms of $A \beta$ may be responsible. For example, acute application of extracellular $\mathrm{A} \beta$ oligomers, in the absence of monomers and fibrils have been shown to inhibit hippocampal LTP in rats in vivo with immunodepletion of all $\mathrm{A} \beta$ species in the preparation abrogating this effect [45]. This study was later refined to show that $A \beta$ oligomers, but not monomers or fibrils were responsible for inhibiting LTP, and an antibody against A $\beta$ prevented such inhibition [46]. This finding relates well to our own studies in 6 month old 3xTg-AD mice where there is no apparent extracellular $A \beta$, suggesting that intraneuronal accumulation is most likely responsible for the deficits in LTP observed. Preliminary data suggest that much of the intracellular $A \beta$ appears to be oligomeric in agreement with these other studies.

In addition to the neurotoxic effects mediated by $\mathrm{A} \beta$, the $\gamma$-secretase-generated carboxy-terminal sequence of APP has emerged as a potential nuclear signalling molecule. This fragment, the AICD, consists of the last 50 carboxy-terminal residues of the APP protein and was initially showed that AICD-like peptides occur in both healthy brains and in the brains of AD patients [47]. Whilst addressing the mechanism through which presenilins modulate calcium signalling, we addressed whether alterations in calcium signalling are mediated as part of the presenilin-dependent $\gamma$-secretase acitivity or as an independent function that is unrelated to its putative protease activity. Genetic ablation of the presenilins attenuated $\mathrm{IP}_{3}$-mediated calcium signalling. These calcium deficits were also observed in cells deficient in APP, and could be rescued by adding back various fragments, provided that APP was intact [31]. These data showed a role for AICD regulating $\mathrm{IP}_{3}$-mediated calcium signalling suggesting a new physiological signalling role for APP. Moreover, this study provided evidence that at least some of presenilins effect's on calcium signalling are due to the $\gamma$ secretase-dependent signalling pathway. However, not all of the presenilin-mediated calcium signalling effects can be accounted for $\gamma$-secretase activity, because the PS1-mediated effects on capacitative calcium entry occur independently of APP [48,49]

\section{Calcium dysregulation as a mechanism underlying A $\beta$-mediated toxicity}

The precise mechanism through which $\mathrm{A} \beta$ exerts its influence on LTP and hence learning and memory is still not understood but is proposed to involve disruption of intracellular calcium homeostasis [50]. Indeed, the role for alterations of intracellular calcium dynamics in modulating LTP was first reported by Bliss and Lomo who showed that intracellular injection of the calcium chelator EGTA reversed the enhancement of LTP reported in hippocampal neurons [51]. More recent evidence has indicated a direct role for the generation of ER calcium elevations in the induction of synaptic plasticity [52]. With these findings in mind, it is interesting to note the substantial body of evidence suggesting that $A \beta$ plays a pivotal role in disrupting intracellular calcium homeostasis. For example a number of studies have shown that $\mathrm{A} \beta$ can alter the activity of a number calciumconducting ion channels such as voltage-gated calcium channels (VGCCs; [53]), NMDA receptors [54] and nicotinic receptors [55]. It is also well documented that $\mathrm{A} \beta$ can form a novel a calcium-conducting pore in lipid bilayers providing a route through which uncontrolled calcium entry may perturb the tightly regulated intracellular calcium environment [56]. In addition to the ability of $A \beta$ to form these calcium-conducting pores in the plasma membrane, extracellular application of $\mathrm{A} \beta$ has been shown to cause a dramatic increase in $\mathrm{IP}_{3}$-mediated calcium release in SH-SY5Y cells [57]. The underlying molecular mechanisms responsible for this enhancement in calcium release from the ER remain to be determined but may be due to a combination of an enhanced intracellular calcium store and/or a failure by the cell, caused by the pathogenic actions of $A \beta$, to regulate calcium elevations.

One pathogenic mechanism through which $A \beta$ has been shown to mediate its effects is via the production of reactive oxygen species (ROS). During the process of A $\beta$ aggregation, hydrogen peroxide and hydroxyl radicals are generated that can result in lipid peroxidation with a subsequent disruption in the activity of ion motive ATPases that are intimately involved in regulating intracellular calcium elevations (such as the calcium-ATPase) [58]. However, the neurotoxic actions of $A \beta$ are not just limited to plasma membrane structures. Studies using PC12 cells have demonstrated that $\mathrm{A} \beta$ can cause inhibition of respiratory chain complexes with a concomitant reduction in cellular ATP levels [59]. The calcium ATPase on the mitochondrial membrane has been shown to be implicitly involved in regulating calcium elevations, any perturbation in mitochondrial function, for example arising from $A \beta$-mediated inhibition of the respiratory chain will 
result in a dramatic alteration in intracellular calcium handling $[60,61]$.

\section{Voltage-gated calcium channels}

It has previously been shown that exogenously applied $\mathrm{A} \beta$ can be neurotoxic, yet this effect is abrogated when cell cultures are incubated in calcium-free solutions [58,62]. These findings suggest that extracellular calcium plays a key role in $\mathrm{A} \beta$-mediated cell death. Furthermore, Brorson and colleagues have demonstrated that micromolar concentrations of $A \beta$ fragments induce a rapid increase in intracellular calcium levels that can be attenuated by the addition of L-type VGCC antagonists [63]. Since these initial findings, numerous groups have reported that incubation with low concentrations of $A \beta$ peptides enhance whole cell calcium currents in a variety of cell lines and primary neurons, as measured by whole cell patch clamping $[53,64,65]$

L-, P- and N-type calcium channel activity can be modulated by $A \beta$ application [53,66-68], which appears to be mediated primarily by $A \beta$-induced production of ROS. Interestingly, post-mortem analysis of $\mathrm{AD}$ brain sections reveals evidence of wide-spread oxidative damage, particularly increased levels of lipid peroxidation, and these levels increase further in areas of extensive neurodegeneration [69]. Membrane phospholipids in the brain are composed of polyunsaturated fatty acids, and as a result of this they are particularly susceptible to free radical attack as their double bonds allow for easy removal of hydrogen atoms. When oxidized, these polyunsaturated fatty acids form aldehydes, particularly 4-hydroxynonenal (HNE), a highly cytotoxic aldehyde which inhibits glycolysis, protein and nucleic acid synthesis leading to apoptosis [70]. Expression of HNE is markedly increased in the AD brain. In addition, when cultured neurons are incubated with $A \beta$, both ROS and HNE levels increase [71]. HNE has been shown to specifically enhance L-type VGCC currents through a mechanism involving increased tyrosine phosphorylation [72]. In addition Peers and colleagues have demonstrated that $A \beta$ can act post-transcriptionally to promote the L-type $\alpha 1 \mathrm{C}$ subunit insertion (or stabilization) into the plasma membrane [73]. Here, these authors used co-immunoprecipitation and co-localisation studies to show that $\mathrm{A} \beta$ associates physically with the ion channel, supporting a physiological role for $A \beta$ in ion channel regulation.

In addition to the effects that $\mathrm{A} \beta$ has on L-type VGCC, $\mathrm{A} \beta$ has also been shown to enhance $\mathrm{Ca}^{2+}$ current through the $\mathrm{N}$ - and L- type VGCCs in synaptosomes and the N- and Ptype VGCCs in cortical neurons [74]. Furthermore, Pearson and colleagues highlighted the importance of the solubility state of $A \beta$, revealing that monomeric, unaggregated $A \beta_{1-40}$ enhanced calcium currents whereas aggregated $A \beta$ had no effect, suggesting a physiological role for $A \beta$ in ion channel regulation in the CNS [75].

\section{A $\beta$ and its role in forming a novel calcium-conducting channel}

In addition to modulating the activity of existing calcium channels, studies indicate that $\mathrm{A} \beta$ can also form novel channels. The first such report described the formation of rudimentary $A \beta$ ion channels in lipid bilayers, alongside similar hydrophobic peptides such as the prion protein associated with Creutzfeldt-Jakob disease [76]. This 'A $\beta$ channel' has been widely investigated in lipid bilayers, allowing for the biophysical and pharmacological characterization of the channel. $A \beta$ has been shown to spontaneously form voltagedependent cation selective channels in lipid bilayers that can conduct calcium [56]. These channels could be blocked by $\mathrm{Zn}^{2+}[77,78]$, by tromethamine and $\mathrm{Al}^{3+}[79]$, and by antibodies against the $A \beta$ peptide itself [80]. It is plausible that $A \beta$ could lead to the formation of novel channels in the plasma membrane and subcellular organelle membranes, thereby causing an unregulated influx of calcium (or other ions) that may contribute to neurodegeneration $[81,82]$. Insertion of these channels into the plasma membranes could slowly cause changes in neuronal membrane potentials leading to alterations in neuronal firing. Furthermore, caspase activation and apoptosis may be initiated following insertion of such channels into specific neuronal organelles such as the ER or mitochondria. Undue stress in the ER has been shown to lead to activation of caspase 12-a caspase implicated in the pathogenesis of $\mathrm{AD}$ [83]. Likewise, formation of these ion channels in the mitochondrial membranes may disrupt mitochondrial membrane potential impairing energy production and leading to apoptosis.

Although the formation of these $A \beta$ channels has been demonstrated in lipid bilayers, the identification of such channels in cell lines has proven difficult. A number of groups have shown that bath application of high concentrations of $A \beta_{1-40}$ $(1-10 \mu \mathrm{M})$ causes a rapid increase in intracellular calcium in human fibroblasts [62] and GT1-7 hypothalamic neurons [76]; both responses were attributed to the formation of $A \beta$ channels. Conclusive evidence for such a channel occurring in a cell line as opposed to a lipid bilayer came from Peers and colleagues who found that periods of chronic hypoxia led to the appearance of novel calcium-conducting channels in PC12 cells [84]. These channels were tightly coupled to the secretion of catecholamine-containing vesicles with secretion blocked not by $\mathrm{Cd}^{2+}$ but instead inhibited by Congo red or an antibody raised against the $\mathrm{N}$-terminal region of $A \beta$. The formation of these channels could be mimicked by exogenous application of $100 \mathrm{nM} \mathrm{A} \beta$ peptides with further analyses demonstrating that whole cell currents through these calcium channels were voltage dependent and very small-less than $1 \mathrm{pA} / \mathrm{pF}$ [85].

There is now an increasing number of reports indicating that $A \beta$ peptides primarily exert their neurotoxic effects whilst in their intermediate oligomeric state, rather than as monomers or fibrils. Demuro et al. have recently highlighted this in SH-SY5Y cells. Bath application of oligomers caused 
a rapid increase in intracellular calcium in SH-SY5Y cells, whereas the monomeric form had no effect [86]. Rather than attributing these increases to the formation of $A \beta$ channels, they suggested that the membrane permeability to calcium ions was altered. The reason for the lack of effect of the monomeric form of the peptide, even amongst a multitude of reports suggesting a role for monomers in forming these $A \beta$ channels and modulating ion channel function, remains to be determined. It is not inconceivable that a small percentage of monomeric $A \beta$ may have formed oligomers to mediate the results these previous researchers observed. The existence of these channels, at least in the laboratory, provides a compelling and intriguing line of research into calcium dyshomeostasis in $\mathrm{AD}$.

\section{Concluding remarks}

Converging evidence from a variety of experimental systems supports an important and proximal pathological role for calcium dyshomeostasis in AD. Despite two decades of research, the precise contribution of dysfunctions in calcium signalling to the pathogenesis of this disease remains unclear. It is well established that $A \beta$ is neurotoxic, and through the advent of transgenic technology there is growing evidence that cognitive dysfunction occurs prior to neuronal cell loss yet correlates with the emergence of intraneuronal $A \beta$ accumulation. This implicates cell dysfunction and not cell loss as the principal cause of learning and memory deficits. One mechanism that may be causing cell dysfunction is alterations in calcium homeostasis produced as a result of intraneuronal $\mathrm{A} \beta$ accumulation. It is well established that cytosolic calcium levels can impact the formation of synaptic plasticity, necessitating a thorough understanding of the role for $A \beta$ in mediating disturbances in intracellular calcium homeostasis. This, however, is further complicated by the ability of $\mathrm{A} \beta$ to exist in various aggregation states, be it as monomers, oligomers or fibrils, with each state appearing to differentially influence not only calcium signaling but also neurotoxicity. To fully elucidate the pathological mechanisms underlying deficits in LTP and learning and memory reported, it is vital to understand the role that each $\mathrm{A} \beta$ species (and its aggregation state) plays either in normal cell physiology or the pathophysiology of AD.

The advent of transgenic technology has given researchers the ability to model human diseases in animals. The majority of the experimental data concerning a role for calcium dyshomeostasis, including our own has been gained using either young (less than a month old) or embryonic neurons, primarily due to technical reasons. With advances in optical imaging and cell culture technology, defects in calcium signalling need to be examined in older animals. A key experiment with regards to the $3 \mathrm{xTg}$-AD mice is to chart alterations in calcium signalling with the development of plaque and tangle pathology. This will enable a better understanding of the role for calcium dysregulation in the emergence of $A \beta$ and tau pathology. This is important as processes that stabilize calcium signals might represent a therapeutic target for treating $\mathrm{AD}$ throughout its course.

\section{Acknowledgements}

This work was supported by grants from the National Institutes of Health (AG17968 and AG16573). We thank Dr. Lauren Billings and Mr. Brain Hitt for critically reading the manuscript.

\section{References}

[1] Y.H. Suh, F. Checler, Amyloid precursor protein, presenilins, and alpha-synuclein: molecular pathogenesis and pharmacological applications in Alzheimer's disease, Pharmacol. Rev. 54 (2002) 469-525.

[2] A. Alzheimer, About a peculiar disease of the cerebral cortex. Translated 1987 by L. Jarvik and H. Greenson. Alzheimer Dis. Assoc. Disord., 1907, 3-8.

[3] K. Ogomori, T. Kitamoto, J. Tateishi, Y. Sato, M. Suetsugu, M. Abe, Beta-protein amyloid is widely distributed in the central nervous system of patients with Alzheimer's disease, Am. J. Pathol. 134 (1989) 243-251.

[4] J. Hardy, D.J. Selkoe, The amyloid hypothesis of Alzheimer's disease: progress and problems on the road to therapeutics, Science 297 (2002) 353-356.

[5] S. Oddo, L. Billings, J.P. Kesslak, D.H. Cribbs, F.M. LaFerla, A $\beta$ immunotherapy leads to clearance of early, but not late, hyperphosphorylated tau aggregates via the proteasome, Neuron. 43 (2004) 321-332.

[6] D.L. Price, R.E. Tanzi, D.R. Borchelt, S.S. Sisodia, Alzheimer's disease: genetic studies and transgenic models, Annu. Rev. Genet. 32 (1998) 461-493.

[7] L.M. Billings, S. Oddo, K.N. Green, J.L. McGaugh, F.M. LaFerla, Intraneuronal $A \beta$ causes the onset of early Alzheimer's diseaserelated cognitive deficits in transgenic mice, Neuron 45 (2005) 675-688.

[8] F.M. LaFerla, Calcium dyshomeostasis and intracellular signalling in Alzheimer's disease, Nat. Rev. Neurosci. 3 (2002) 862-872.

[9] M. Shoji, T.E. Golde, J. Ghiso, T.T. Cheung, S. Estus, L.M. Shaffer, X.D. Cai, D.M. McKay, R. Tintner, B. Frangione, et al., Production of the Alzheimer amyloid beta protein by normal proteolytic processing, Science 258 (1992) 126-129.

[10] J.D. Buxbaum, K.N. Liu, Y. Luo, J.L. Slack, K.L. Stocking, J.J. Peschon, R.S. Johnson, B.J. Castner, D.P. Cerretti, R.A. Black, Evidence that tumor necrosis factor alpha converting enzyme is involved in regulated alpha-secretase cleavage of the Alzheimer amyloid protein precursor, J. Biol. Chem. 273 (1998) 27765-27767.

[11] S. Lammich, E. Kojro, R. Postina, S. Gilbert, R. Pfeiffer, M. Jasionowski, C. Haass, F. Fahrenholz, Constitutive and regulated alpha-secretase cleavage of Alzheimer's amyloid precursor protein by a disintegrin metalloprotease, Proc. Natl. Acad. Sci. USA 96 (1999) 3922-3927.

[12] R. Vassar, B.D. Bennett, S. Babu-Khan, S. Kahn, E.A. Mendiaz, P. Denis, D.B. Teplow, S. Ross, P. Amarante, R. Loeloff, Y. Luo, S. Fisher, J. Fuller, S. Edenson, J. Lile, M.A. Jarosinski, A.L. Biere, E. Curran, T. Burgess, J.C. Louis, F. Collins, J. Treanor, G. Rogers, M. Citron, Beta-secretase cleavage of Alzheimer's amyloid precursor protein by the transmembrane aspartic protease BACE, Science 286 (1999) 735-741. 
[13] I. Hussain, D. Powell, D.R. Howlett, D.G. Tew, T.D. Meek, C. Chapman, I.S. Gloger, K.E. Murphy, C.D. Southan, D.M. Ryan, T.S. Smith, D.L. Simmons, F.S. Walsh, C. Dingwall, G. Christie, Identification of a novel aspartic protease (Asp 2) as beta-secretase, Mol. Cell Neurosci. 14 (1999) 419-427.

[14] S. Sinha, J.P. Anderson, R. Barbour, G.S. Basi, R. Caccavello, D. Davis, M. Doan, H.F. Dovey, N. Frigon, J. Hong, K. JacobsonCroak, N. Jewett, P. Keim, J. Knops, I. Lieberburg, M. Power, H. Tan, G. Tatsuno, J. Tung, D. Schenk, P. Seubert, S.M. Suomensaari, S. Wang, D. Walker, J. Zhao, L. McConlogue, V. John, Purification and cloning of amyloid precursor protein beta-secretase from human brain, Nature 402 (1999) 537-540.

[15] H. Steiner, E. Winkler, D. Edbauer, S. Prokop, G. Basset, A. Yamasaki, M. Kostka, C. Haass, PEN-2 is an integral component of the gamma-secretase complex required for coordinated expression of presenilin and nicastrin, J. Biol. Chem. 277 (2002) 39062-39065.

[16] R. Francis, G. McGrath, J. Zhang, D.A. Ruddy, M. Sym, J. Apfeld, M. Nicoll, M. Maxwell, B. Hai, M.C. Ellis, A.L. Parks, W. Xu, J. Li, M. Gurney, R.L. Myers, C.S. Himes, R. Hiebsch, C. Ruble, J.S. Nye, D. Curtis, aph-1 and pen-2 are required for Notch pathway signaling, gamma-secretase cleavage of betaAPP, and presenilin protein accumulation, Dev. Cell 3 (2002) 85-97.

[17] D. Levitan, J. Lee, L. Song, R. Manning, G. Wong, E. Parker, L. Zhang, PS1 N- and C-terminal fragments form a complex that functions in APP processing and Notch signalling, Proc. Natl. Acad. Sci. USA 98 (2001) 12186-12190.

[18] B. De Strooper, P. Saftig, K. Craessaerts, H. Vanderstichele, G. Guhde, W. Annaert, K. Von Figura, F. Van Leuven, Deficiency of presenilin-1 inhibits the normal cleavage of amyloid precursor protein, Nature 391 (1998) 387-390.

[19] C. Haass, A.Y. Hung, M.G. Schlossmacher, D.B. Teplow, D.J. Selkoe, beta-Amyloid peptide and a 3-kDa fragment are derived by distinct cellular mechanisms, J. Biol. Chem. 268 (1993) 30213024.

[20] J.T. Jarrett, E.P. Berger, P.T. Lansbury Jr., The carboxy terminus of the beta amyloid protein is critical for the seeding of amyloid formation: implications for the pathogenesis of Alzheimer's disease, Biochemistry 32 (1993) 4693-4697.

[21] C.C. Glabe, Amyloid accumulation and pathogensis of Alzheimer's disease: significance of monomeric, oligomeric and fibrillar Abeta, Subcell. Biochem. 38 (2005) 167-177.

[22] R. Sherrington, E.I. Rogaev, Y. Liang, E.A. Rogaeva, G. Levesque, M. Ikeda, H. Chi, C. Lin, G. Li, K. Holman, et al., Cloning of a gene bearing missense mutations in early-onset familial Alzheimer's disease, Nature 375 (1995) 754-760.

[23] E. Levy-Lahad, W. Wasco, P. Poorkaj, D.M. Romano, J. Oshima, W.H. Pettingell, C.E. Yu, P.D. Jondro, S.D. Schmidt, K. Wang, et al., Candidate gene for the chromosome 1 familial Alzheimer's disease locus, Science 269 (1995) 973-977.

[24] D.J. Selkoe, M.B. Podlisny, Deciphering the genetic basis of Alzheimer's disease, Annu. Rev. Genomics Hum. Genet. 3 (2002) 67-99.

[25] D. Scheuner, C. Eckman, M. Jensen, X. Song, M. Citron, N. Suzuki, T.D. Bird, J. Hardy, M. Hutton, W. Kukull, E. Larson, E. Levy-Lahad, M. Viitanen, E. Peskind, P. Poorkaj, G. Schellenberg, R. Tanzi, W. Wasco, L. Lannfelt, D. Selkoe, S. Younkin, Secreted amyloid beta-protein similar to that in the senile plaques of Alzheimer's disease is increased in vivo by the presenilin 1 and 2 and APP mutations linked to familial Alzheimer's disease, Nat. Med. 2 (1996) 864-870.

[26] Q. Guo, K. Furukawa, B.L. Sopher, D.G. Pham, J. Xie, N. Robinson, G.M. Martin, M.P. Mattson, Alzheimer's PS-1 mutation perturbs calcium homeostasis and sensitizes PC12 cells to death induced by amyloid beta-peptide, Neuroreport 8 (1996) 379-383.

[27] Q. Guo, S. Christakos, N. Robinson, M.P. Mattson, Calbindin D28k blocks the proapoptotic actions of mutant presenilin 1: reduced oxidative stress and preserved mitochondrial function, Proc. Natl. Acad. Sci. USA 95 (1998) 3227-3232.

[28] M.A. Leissring, Y. Akbari, C.M. Fanger, M.D. Cahalan, M.P. Mattson, F.M. LaFerla, Capacitative calcium entry deficits and elevated luminal calcium content in mutant presenilin-1 knockin mice, J. Cell Biol. 149 (2000) 793-798.

[29] M.A. Leissring, B.A. Paul, I. Parker, C.W. Cotman, F.M. LaFerla, Alzheimer's presenilin-1 mutation potentiates inositol 1,4,5trisphosphate-mediated calcium signaling in Xenopus oocytes, J. Neurochem. 72 (1999) 1061-1068.

[30] M.A. Leissring, I. Parker, F.M. LaFerla, Presenilin-2 mutations modulate amplitude and kinetics of inositol 1,4,5-trisphosphatemediated calcium signals, J. Biol. Chem. 274 (1999) 32535-32538.

[31] M.A. Leissring, M.P. Murphy, T.R. Mead, Y. Akbari, M.C. Sugarman, M. Jannatipour, B. Anliker, U. Muller, P. Saftig, B. De Strooper, M.S. Wolfe, T.E. Golde, F.M. LaFerla, A physiologic signaling role for the gamma -secretase-derived intracellular fragment of APP, Proc. Natl. Acad. Sci. USA 99 (2002) 46974702.

[32] Q. Guo, W. Fu, B.L. Sopher, M.W. Miller, C.B. Ware, G.M. Martin, M.P. Mattson, Increased vulnerability of hippocampal neurons to excitotoxic necrosis in presenilin-1 mutant knock-in mice, Nat. Med. 5 (1999) 101-106.

[33] S.L. Chan, M. Mayne, C.P. Holden, J.D. Geiger, M.P. Mattson, Presenilin-1 mutations increase levels of ryanodine receptors and calcium release in PC12 cells and cortical neurons, J. Biol. Chem. 275 (2000) 18195-18200.

[34] G.E. Stutzmann, A. Caccamo, F.M. LaFerla, I. Parker, Dysregulated IP3 signaling in cortical neurons of knock-in mice expressing an Alzheimer's-linked mutation in presenilin1 results in exaggerated calcium signals and altered membrane excitability, J. Neurosci. 24 (2004) 508-513.

[35] C.R. Rose, A. Konnerth, Stores not just for storage. intracellular calcium release and synaptic plasticity, Neuron 31 (2001) 519-522.

[36] P.A. Barrow, R.M. Empson, S.J. Gladwell, C.M. Anderson, R. Killick, X. Yu, J.G. Jefferys, K. Duff, Functional phenotype in transgenic mice expressing mutant human presenilin-1, Neurobiol. Dis. 7 (2000) 119-126.

[37] A. Parent, D.J. Linden, S.S. Sisodia, D.R. Borchelt, Synaptic transmission and hippocampal long-term potentiation in transgenic mice expressing FAD-linked presenilin 1, Neurobiol. Dis. 6 (1999) $56-62$.

[38] S. Oddo, A. Caccamo, J.D. Shepherd, M.P. Murphy, T.E. Golde, R. Kayed, R. Metherate, M.P. Mattson, Y. Akbari, F.M. LaFerla, Triple-transgenic model of Alzheimer's disease with plaques and tangles: intracellular $\mathrm{A} \beta$ and synaptic dysfunction, Neuron. 39 (2003) 409-421.

[39] I.F. Smith. B. Hitt, K.N. Green, S. Oddo, F.M. LaFerla, Enhanced caffeine-induced calcium release in the $3 \times \mathrm{Tg}-\mathrm{AD}$ model of Alzheimer's disease. J. Neurochem. 2005, in press.

[40] R. Etcheberrigaray, N. Hirashima, L. Nee, J. Prince, S. Govoni, M. Racchi, R.E. Tanzi, D.L. Alkon, Calcium responses in fibroblasts from asymptomatic members of Alzheimer's disease families, Neurobiol. Dis. 5 (1998) 37-45.

[41] R.S. Zucker, W.G. Regehr, Short-term synaptic plasticity, Annu. Rev. Physiol. 64 (2002) 355-405.

[42] A.M. Thomson, Facilitation, augmentation and potentiation at central synapses, Trends Neurosci. 23 (2000) 305-312.

[43] T.V. Bliss, G.L. Collingridge, A synaptic model of memory: longterm potentiation in the hippocampus, Nature 361 (1993) 31-39.

[44] F. Kamenetz, T. Tomita, H. Hsieh, G. Seabrook, D. Borchelt, T. Iwatsubo, S. Sisodia, R. Malinow, APP processing and synaptic function, Neuron 37 (2003) 925-937.

[45] D.M. Walsh, I. Klyubin, J.V. Fadeeva, W.K. Cullen, R. Anwyl, M.S. Wolfe, M.J. Rowan, D.J. Selkoe, Naturally secreted oligomers of amyloid beta protein potently inhibit hippocampal long-term potentiation in vivo, Nature 416 (2002) 535-539. 
[46] I. Klyubin, D.M. Walsh, C.A. Lemere, W.K. Cullen, G.M. Shankar, V. Betts, E.T. Spooner, L. Jiang, R. Anwyl, D.J. Selkoe, M.J. Rowan, Amyloid beta protein immunotherapy neutralizes Abeta oligomers that disrupt synaptic plasticity in vivo, Nat. Med. (2005).

[47] B. Passer, L. Pellegrini, C. Russo, R.M. Siegel, M.J. Lenardo, G. Schettini, M. Bachmann, M. Tabaton, L. D'Adamio, Generation of an apoptotic intracellular peptide by gamma-secretase cleavage of Alzheimer's amyloid beta protein precursor, J. Alzheimers Dis. 2 (2000) 289-301.

[48] J. Herms, I. Schneider, I. Dewachter, N. Caluwaerts, H. Kretzschmar, F. Van Leuven, Capacitive calcium entry is directly attenuated by mutant presenilin-1, independent of the expression of the amyloid precursor protein, J. Biol. Chem. 278 (2003) 2484-2489.

[49] Y. Akbari, B.D. Hitt, M.P. Murphy, N.N. Dagher, B.P. Tseng, K.N. Green, T.E. Golde, F.M. LaFerla, Presenilin regulates capacitative calcium entry dependently and independently of gamma-secretase activity, Biochem. Biophys. Res. Commun. 322 (2004) 1145-1152.

[50] M.P. Mattson, Pathways towards and away from Alzheimer's disease, Nature 430 (2004) 631-639.

[51] T.V. Bliss, T. Lomo, Long-lasting potentiation of synaptic transmission in the dentate area of the anaesthetized rabbit following stimulation of the perforant path, J. Physiol. 232 (1973) 331-356.

[52] S.M. Fitzjohn, G.L. Collingridge, Calcium stores and synaptic plasticity, Cell Calcium 32 (2002) 405-411.

[53] K. Ueda, S. Shinohara, T. Yagami, K. Asakura, K. Kawasaki, Amyloid beta protein potentiates Calcium influx through L-type voltage-sensitive Calcium channels: a possible involvement of free radicals, J. Neurochem. 68 (1997) 265-271.

[54] J. Wu, R. Anwyl, M.J. Rowan, beta-Amyloid selectively augments NMDA receptor-mediated synaptic transmission in rat hippocampus, Neuroreport 6 (1995) 2409-2413.

[55] J.J. Dougherty, J. Wu, R.A. Nichols, Beta-amyloid regulation of presynaptic nicotinic receptors in rat hippocampus and neocortex, J. Neurosci. 23 (2003) 6740-6747.

[56] N. Arispe, H.B. Pollard, E. Rojas, Giant multilevel cation channels formed by Alzheimer disease amyloid beta-protein $[A \beta-(1-40)]$ in bilayer membranes, Proc. Natl. Acad. Sci. USA 90 (1993) 10573-10577.

[57] I.F. Smith, J.P. Boyle, P.F. Vaughan, H.A. Pearson, C. Peers, Effects of chronic hypoxia on calcium stores and capacitative calcium entry in human neuroblastoma (SH-SY5Y) cells, J. Neurochem. 79 (2001) 877-884.

[58] R.J. Mark, K. Hensley, D.A. Butterfield, M.P. Mattson, Amyloid beta-peptide impairs ion-motive ATPase activities: evidence for a role in loss of neuronal calcium homeostasis and cell death, J. Neurosci. 15 (1995) 6239-6249.

[59] C.S. Casley, J.M. Land, M.A. Sharpe, J.B. Clark, M.R. Duchen, L. Canevari, Beta-amyloid fragment 25-35 causes mitochondrial dysfunction in primary cortical neurons, Neurobiol. Dis. 10 (2002) 258-267.

[60] E. Boitier, R. Rea, M.R. Duchen, Mitochondria exert a negative feedback on the propagation of intracellular calcium waves in rat cortical astrocytes, J. Cell Biol. 145 (1999) 795-808.

[61] M.J. Berridge, M.D. Bootman, H.L. Roderick, Calcium signalling: dynamics, homeostasis and remodelling, Nat. Rev. Mol. Cell Biol. 4 (2003) 517-529.

[62] Y.J. Zhu, H. Lin, R. Lal, Fresh and nonfibrillar amyloid beta protein $(1-40)$ induces rapid cellular degeneration in aged human fibroblasts: evidence for AbetaP-channel-mediated cellular toxicity, Faseb. J. 14 (2000) 1244-1254.

[63] J.R. Brorson, V.P. Bindokas, T. Iwama, C.J. Marcuccilli, J.C. Chisholm, R.J. Miller, The calcium influx induced by beta-amyloid peptide $25-35$ in cultured hippocampal neurons results from network excitation, J. Neurobiol. 26 (1995) 325-338.

[64] J.H. Weiss, C.J. Pike, C.W. Cotman, Calcium channel blockers attenuate beta-amyloid peptide toxicity to cortical neurons in culture, J. Neurochem. 62 (1994) 372-375.
[65] R.M. Davidson, L. Shajenko, T.S. Donta, Amyloid beta-peptide $\mathrm{A} \beta$ potentiates a nimodipine-sensitive L-type barium conductance in N1E-115 neuroblastoma cells, Brain Res. 643 (1994) 324 327.

[66] F.J. Ekinci, K.U. Malik, T.B. Shea, Activation of the L voltagesensitive calcium channel by mitogen-activated protein (MAP) kinase following exposure of neuronal cells to beta-amyloid. MAP kinase mediates beta-amyloid-induced neurodegeneration, J. Biol. Chem. 274 (1999) 30322-30327.

[67] K.N. Green, C. Peers, Divergent pathways account for two distinct effects of amyloid beta peptides on exocytosis and calcium currents: involvement of ROS and NF-kappaB, J. Neurochem. 81 (2002) 1043-1051.

[68] S.T. Brown, J.L. Scragg, J.P. Boyle, K. Hudasek, C. Peers, I.M. Fearon, Hypoxic augmentation of calcium channel currents requires a functional electron transport chain, J. Biol. Chem. (2005).

[69] W.R. Markesbery, J.M. Carney, Oxidative alterations in Alzheimer's disease, Brain Pathol. 9 (1999) 133-146.

[70] R.J. Mark, M.A. Lovell, W.R. Markesbery, K. Uchida, M.P. Mattson, A role for 4-hydroxynonenal, an aldehydic product of lipid peroxidation, in disruption of ion homeostasis and neuronal death induced by amyloid beta-peptide, J. Neurochem. 68 (1997) 255-264.

[71] J.N. Keller, Z. Pang, J.W. Geddes, J.G. Begley, A. Germeyer, G. Waeg, M.P. Mattson, Impairment of glucose and glutamate transport and induction of mitochondrial oxidative stress and dysfunction in synaptosomes by amyloid beta-peptide: role of the lipid peroxidation product 4-hydroxynonenal, J. Neurochem. 69 (1997) 273-284.

[72] C. Lu, S.L. Chan, W. Fu, M.P. Mattson, The lipid peroxidation product 4-hydroxynonenal facilitates opening of voltagedependent calcium channels in neurons by increasing protein tyrosine phosphorylation, J. Biol. Chem. 277 (2002) 2436824375.

[73] J.L. Scragg, I.M. Fearon, J.P. Boyle, S.G. Ball, G. Varadi, C. Peers, Alzheimer's amyloid peptides mediate hypoxic up-regulation of Ltype calcium channels, Faseb. J. 19 (2005) 150-152.

[74] A. MacManus, M. Ramsden, M. Murray, Z. Henderson, H.A. Pearson, V.A. Campbell, Enhancement of ${ }^{(45)}$ calcium influx and voltage-dependent calcium channel activity by beta-amyloid-(1-40) in rat cortical synaptosomes and cultured cortical neurons. Modulation by the proinflammatory cytokine interleukin-1beta, J. Biol. Chem. 275 (2000) 4713-4718.

[75] M. Ramsden, L.D. Plant, N.J. Webster, P.F. Vaughan, Z. Henderson, H.A. Pearson, Differential effects of unaggregated and aggregated amyloid beta protein $(1-40)$ on $\mathrm{K}^{+}$channel currents in primary cultures of rat cerebellar granule and cortical neurones, J. Neurochem. 79 (2001) 699-712.

[76] M. Kawahara, Y. Kuroda, N. Arispe, E. Rojas, Alzheimer's betaamyloid, human islet amylin, and prion protein fragment evoke intracellular free calcium elevations by a common mechanism in a hypothalamic GnRH neuronal cell line, J. Biol. Chem. 275 (2000) 14077-14083.

[77] M. Kawahara, N. Arispe, Y. Kuroda, E. Rojas, Alzheimer's disease amyloid beta-protein forms $\mathrm{Zn}^{2+}$-sensitive, cation-selective channels across excised membrane patches from hypothalamic neurons, Biophys. J. 73 (1997) 67-75.

[78] N. Arispe, H.B. Pollard, E. Rojas, $\mathrm{Zn}^{2+}$ interaction with Alzheimer amyloid beta protein calcium channels, Proc. Natl. Acad. Sci. USA 93 (1996) 1710-1715.

[79] N. Arispe, E. Rojas, H.B. Pollard, Alzheimer disease amyloid beta protein forms calcium channels in bilayer membranes: blockade by tromethamine and aluminium, Proc. Natl. Acad. Sci. USA 90 (1993) 567-571.

[80] S.K. Rhee, A.P. Quist, R. Lal, Amyloid beta protein-(1-42) forms calcium-permeable, $\mathrm{Zn}^{2+}$-sensitive channel, J. Biol. Chem. 273 (1998) 13379-13382. 
[81] H.B. Pollard, N. Arispe, E. Rojas, Ion channel hypothesis for Alzheimer amyloid peptide neurotoxicity, Cell Mol. Neurobiol. 15 (1995) 513-526.

[82] N. Arispe, H.B. Pollard, E. Rojas, beta-Amyloid calcium-channel hypothesis for neuronal death in Alzheimer disease, Mol. Cell Biochem. 140 (1994) 119-125.

[83] T. Nakagawa, H. Zhu, N. Morishima, E. Li, J. Xu, B.A. Yankner, J. Yuan, Caspase-12 mediates endoplasmic-reticulum-specific apoptosis and cytotoxicity by amyloid-beta, Nature 403 (2000) 98-103.

[84] S.C. Taylor, T.F. Batten, C. Peers, Hypoxic enhancement of quantal catecholamine secretion. Evidence for the involvement of amyloid beta-peptides, J. Biol. Chem. 274 (1999) 31217-31222.

[85] K.N. Green, C. Peers, Amyloid beta peptides mediate hypoxic augmentation of calcium channels, J. Neurochem. 77 (2001) 953-956.

[86] A. Demuro, E. Mina, R. Kayed, S.C. Milton, I. Parker, C.G. Glabe, Calcium dysregulation and membrane disruption as a ubiquitous neurotoxic mechanism of soluble amyloid oligomers, J. Biol. Chem. 280 (2005) 17294-17300.

[87] J.G. Begley, W. Duan, S. Chan, K. Duff, M.P. Mattson, Altered calcium homeostasis and mitochondrial dysfunction in cortical synaptic compartments of presenilin-1 mutant mice, J. Neurochem. 72 (1999) 1030-1039.

[88] Q. Guo, L. Sebastian, B.L. Sopher, M.W. Miller, C.B. Ware, G.M. Martin, M.P. Mattson, Increased vulnerability of hippocampal neurons from presenilin-1 mutant knock-in mice to amyloid beta-peptide toxicity: central roles of superoxide production and caspase activation, J. Neurochem. 72 (1999) 1019-1029.

[89] D.H. Chui, H. Tanahashi, K. Ozawa, S. Ikeda, F. Checler, O. Ueda, H. Suzuki, W. Araki, H. Inoue, K. Shirotani, K. Takahashi, F. Gallyas, T. Tabira, Transgenic mice with Alzheimer presenilin 1 mutations show accelerated neurodegeneration without amyloid plaque formation, Nat. Med. 5 (1999) 560-564.

[90] G.E. Gibson, H. Zhang, L. Toral-Barza, S. Szolosi, B. TofelGrehl, Calcium stores in cultured fibroblasts and their changes with Alzheimer's disease, Biochim. Biophys. Acta 1316 (1996) 71-77.

[91] G.E. Gibson, P. Nielsen, K.A. Sherman, J.P. Blass, Diminished mitogen-induced calcium uptake by lymphocytes from Alzheimer patients, Biol. Psychiatry 22 (1987) 1079-1086.

[92] N. Hirashima, R. Etcheberrigaray, S. Bergamaschi, M. Racchi, F. Battaini, G. Binetti, S. Govoni, D.L. Alkon, Calcium responses in human fibroblasts: a diagnostic molecular profile for Alzheimer's disease, Neurobiol. Aging 17 (1996) 549-555.

[93] C. Peterson, R.R. Ratan, M.L. Shelanski, J.E. Goldman, Cytosolic free calcium and cell spreading decrease in fibroblasts from aged and Alzheimer donors, Proc. Natl. Acad. Sci. USA 83 (1986) 7999-8001.

[94] C. Peterson, G.E. Gibson, J.P. Blass, Altered calcium uptake in cultured skin fibroblasts from patients with Alzheimer's disease, $\mathrm{N}$ Engl J Med 312 (1985) 1063-1065.

[95] C. Peterson, J.E. Goldman, Alterations in calcium content and biochemical processes in cultured skin fibroblasts from aged and Alzheimer donors, Proc. Natl. Acad. Sci. USA 83 (1986) 2758-2762.

[96] C. Peterson, R.R. Ratan, M.L. Shelanski, J.E. Goldman, Altered response of fibroblasts from aged and Alzheimer donors to drugs that elevate cytosolic free calcium, Neurobiol. Aging 9 (1988) 261-266.
[97] C. Peterson, R. Ratan, M. Shelanski, J. Goldman, Changes in calcium homeostasis during aging and Alzheimer's disease, Ann. N Y Acad. Sci. 568 (1989) 262-270

[98] Y. Tatebayashi, M. Takeda, Y. Kashiwagi, M. Okochi, T. Kurumadani, A. Sekiyama, G. Kanayama, S. Hariguchi, T. Nishimura, Cell-cycle-dependent abnormal calcium response in fibroblasts from patients with familial Alzheimer's disease, Dementia 6 (1995) 9-16.

[99] Q. Guo, B.L. Sopher, K. Furukawa, D.G. Pham, N. Robinson, G.M. Martin, M.P. Mattson, Alzheimer's presenilin mutation sensitizes neural cells to apoptosis induced by trophic factor withdrawal and amyloid beta-peptide: involvement of calcium and oxyradicals, J. Neurosci. 17 (1997) 4212-4222.

[100] J.N. Keller, Q. Guo, F.W. Holtsberg, A.J. Bruce-Keller, M.P. Mattson, Increased sensitivity to mitochondrial toxin-induced apoptosis in neural cells expressing mutant presenilin-1 is linked to perturbed calcium homeostasis and enhanced oxyradical production, J. Neurosci. 18 (1998) 4439-4450.

[101] K. Furukawa, Q. Guo, G.D. Schellenberg, M.P. Mattson, Presenilin1 mutation alters NGF-induced neurite outgrowth, calcium homeostasis, and transcription factor (AP-1) activation in PC12 cells, J. Neurosci. Res. 52 (1998) 618-624.

[102] B.O. Popescu, A. Cedazo-Minguez, L.M. Popescu, B. Winblad, R.F. Cowburn, M. Ankarcrona, Caspase cleavage of exon 9 deleted presenilin-1 is an early event in apoptosis induced by calcium ionophore A 23187 in SH-SY5Y neuroblastoma cells, J. Neurosci. Res. 66 (2001) 122-134.

[103] I.F. Smith, J.P. Boyle, P.F.T. Vaughan, H.A. Pearson, R.F. Cowburn, C.S. Peers, Calcium stores and capacitative calcium entry in human neuroblastoma (SH-SY5Y) cells expressing a familial Alzheimer's disease presenilin-1 mutation. Brain Res. 949 (2002) 105-111.

[104] A. Cedazo-Minguez, B.O. Popescu, M. Ankarcrona, T. Nishimura, R.F. Cowburn, The presenilin 1 \{capital delta\}E9 mutation gives enhanced basal phospholipase $\mathrm{C}$ activity and a resultant increase in intracellular calcium concentrations, J. Biol. Chem. (2002).

[105] A.S. Yoo, I. Cheng, S. Chung, T.Z. Grenfell, H. Lee, E. PackChung, M. Handler, J. Shen, W. Xia, G. Tesco, A.J. Saunders, K. Ding, M.P. Frosch, R.E. Tanzi, T.W. Kim, Presenilin-mediated modulation of capacitative calcium entry, Neuron 27 (2000) 561572.

[106] M. Nakajima, M. Miura, T. Aosaki, T. Shirasawa, Deficiency of presenilin-1 increases calcium-dependent vulnerability of neurons to oxidative stress in vitro, J. Neurochem. 78 (2001) 807-814.

[107] C.B. Lessard, M.P. Lussier, S. Cayouette, G. Bourque, G. Boulay, The overexpression of presenilin2 and Alzheimer's-disease-linked presenilin2 variants influences TRPC6-enhanced calcium entry into HEK293 cells, Cell Signal 17 (2005) 437-445.

[108] I. Schneider, D. Reverse, I. Dewachter, L. Ris, N. Caluwaerts, C. Kuiperi, M. Gilis, H. Geerts, H. Kretzschmar, E. Godaux, D. Moechars, F. Van Leuven, J. Herms, Mutant presenilins disturb neuronal calcium homeostasis in the brain of transgenic mice, decreasing the threshold for excitotoxicity and facilitating longterm potentiation, J. Biol. Chem. 276 (2001) 11539-11544.

[109] G. Zatti, R. Ghidoni, L. Barbiero, G. Binetti, T. Pozzan, C. Fasolato, P. Pizzo, The presenilin 2 M239I mutation associated with familial Alzheimer's disease reduces calcium release from intracellular stores, Neurobiol. Dis. 15 (2004) 269-278. 